\title{
Constrictive Entrapment Neuropathies of a Limb Secondary to Restraint Strapping: A Case Report
}

\section{Tiffany Ella Rose Say, MDa, Raymond L. Rosales, MD, PhDa,b}

\section{ABSTRACT}

Rationale: Entrapment neuropathies are peripheral nerve disorders at specific anatomical locations. They may be caused by trauma in a manner of sprains or bone fracture, but it is often caused by repetitive insults or compression of nerves as they travel through a narrow anatomic space. Pregnancy and pre-existing comorbidities such as diabetes, obesity, cancer, or autoimmune diseases may also cause nerve entrapment.

Objective: To highlight the case of a 52-yearold female developing right foot dysesthesia and weakness after continuous restraint strapping from her previous hospitalization.

Case: Here we have the case of a 52-year-old Filipino female consulted because of right foot dysesthesia, allodynia, and mild weakness. She had a history of bipolar disorder and recent onset of acute psychosis and overdosing with her irregularly taken maintenance olanzapine tablets. She was put on restraint strapping of the right lower limb in her one-week hospital stay. This resulted in developing restraint marks on her right ankle accompanied by difficulty walking on heels and toes, spontaneous dysesthesia, and touch allodynia of her entire right foot. An electrodiagnosis yielded right lower limb

Tiffany Ella Rose Say

tiffanysay17@gmail.com

a. The Department of Internal Medicine and Center for Neurodiagnostic and Therapeutic Services, Metropolitan Medical Center, Manila, Philippines

b. The Faculty of Medicine and Surgery Research Center for Health Sciences, University of Santo Tomas, Manila, Philippines focal neuropathies involving the right fibular nerve, right tibial nerve, right superficial fibular, and right sural nerves. The prescribed amitriptyline and gabapentin for 6 months led to gradual improvement of neuropathic pain.

Discussion and Summary: Our case exemplifies focal limb neuropathies from entrapment due to restraint strapping. Electrodiagnostic confirmation of neuropathies of the same limb sensory and motor nerves was mandated to corroborate clinical neuropathic pain and after ruling out other causes of entrapment neuropathies. Prolonged use of neuropathic pain medications were needed to attain relief in this present case. Restrictive strapping is an iatrogenic cause of entrapment neuropathy that is preventable, had there been proper medical attention applied.

Key words: Entrapment neuropathy, mononeuropathy, iatrogenic, nerve compression syndrome, restraints, focal neuropathy, case report

\section{INTRODUCTION}

Entrapment neuropathies, also known as nerve compression syndromes, are disorders affecting peripheral nerves that develop when they are compressed and restricted. It results from various causes such as trauma, injury, or overused activity. This condition is characterized by pain and/or loss of function of a nerve as a result of chronic compression. These nerves are compressed or entrapped atvarious regions of extremities, especially at "tunnel" regions, where they are predisposed to compression. Carpal tunnel syndrome is the most common entrapment neuropathy followed by cubital tunnel syndrome.[1] 


\section{CASE PRESENTATION}

\section{Patient History}

A 52-year-old Filipino female, single, and a diagnosed case of bipolar disorder, but of whom there were no comorbidities like diabetes mellitus and renal disease, presented at the emergency room due to acute psychosis and medicine overdosing (50 tablets of $10 \mathrm{mg}$ olanzapine). In view of her psychotic episode, restlessness and agitation, she was put on continuous 4-point strapping restraints during her one week of hospital stay elsewhere. Within one week from hospital discharge, she complained of dysesthesia (pins and needles) over the dorsum and sole of the right foot. In addition, she also noted numbness but had touch allodynia over the dorsum of the same foot. She also complained mild weakness of the right foot upon walking.

\section{Examination Findings}

Focus was made on her affected right foot showing keloid formation but had no skin ulceration, discolored patches, purpuric lesions or temperature and nail changes (Figure 1). Blood panels that included hematologic and metabolic workups were found not yielding. There were no indications of an

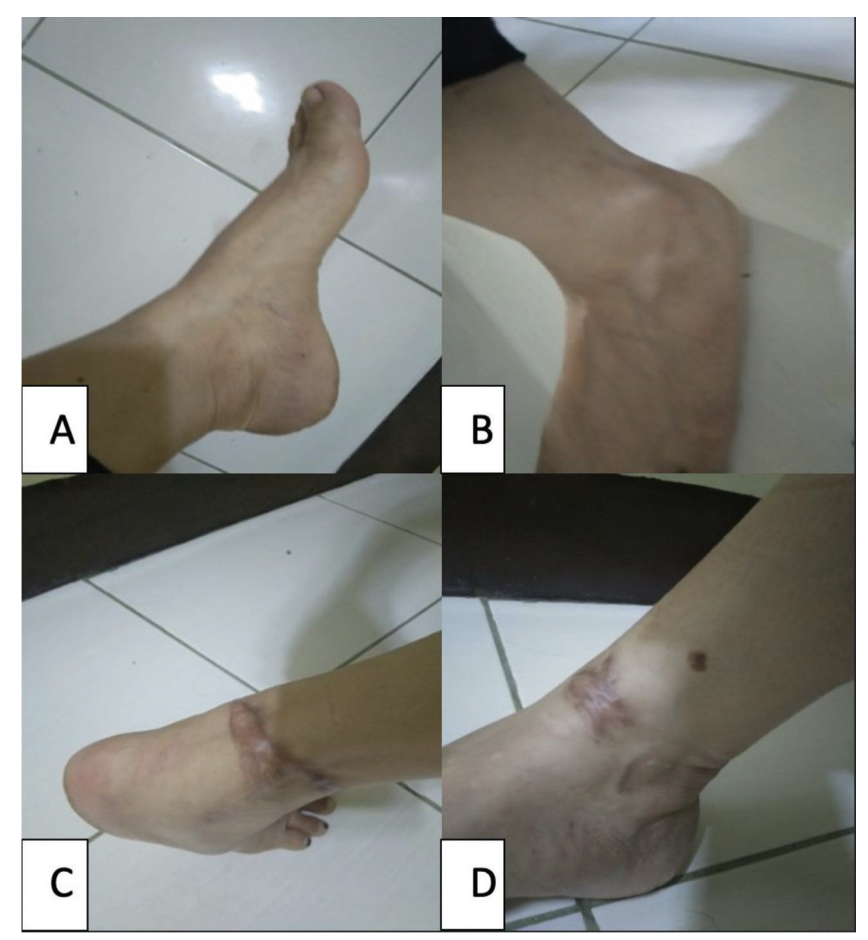

Figure 1: Figures $A$ and $B$ show the patient's left ankle with no apparent restraint marks while Figures $C$ and $D$ show patient's right ankle with keloid scars from constrictive strapping autoimmune disorder to potentially cause vasculitic neuropathy.[2] Electrodiagnostic tests along the four limbs showed focal neuropathies of the right fibular motor nerve, right tibial motor nerve, right sural, and right superficial fibular nerves, but had no evidence of diffuse neuropathies or myopathy. The focal neuropathies mainly indicated axonopathies, in view of absent or reduced amplitudes of compound muscle and sensory evoked potentials (Table 1), yet had normal findings in the other nerves from the three limbs.

\section{Treatment}

The neuropathic pain (ie,. dysesthesia and allodynia of the right foot) of the patient gradually responded over a period of 6 months with combined treatment of amitriptyline $25 \mathrm{mg}$ daily and gabapentin 900 mg daily.

\section{DISCUSSION}

Focal neuropathies arise from nerve entrapments, infections (eg, Hansen's disease), vasculitis, nerve injuries, dysimmune disorders (eg, multifocal motor neuropathy), and even metabolic disorders (eg, diabetes mellitus). Early detection of neuropathy has a greater chance of reversing or slowing the progression if treated early. Repetitive injury or trauma to a nerve lead to microvascular changes, edema, and injury to the myelin sheath that aids in transmitting nerve signals. [3] Left unattended, motor and sensory nerve axonopathy could set in, and in which situation, treatment may become challenging or prolonged from clinical sequela (eg, neuropathic pain, numbness, and muscle weakness). Entrapment neuropathies are secondary to compression and/ or irritation of peripheral nerves as they pass through a narrow anatomical canal. Its etiology remains largely unknown with several known risk factors that predispose patients to develop entrapment neuropathies such as increased body mass index, occupational or physical causes, and predisposing comorbidities such as diabetes or hypothyroidism. Genetic predisposition is currently emerging as one of the strongest risk factors for entrapment neuropathies.[4] For this present case, focal limb entrapment neuropathies that involved motor and sensory nerves occurred following constrictive and continuous strapping for a period 
Table 1: Motor and Sensory Nerve Conduction Studies of the Case

\begin{tabular}{|c|c|c|c|c|c|c|c|c|c|c|c|}
\hline \multirow[t]{2}{*}{ Nerve } & \multirow[t]{2}{*}{ Stimulus } & \multirow[t]{2}{*}{ Recording } & \multicolumn{2}{|c|}{ LatOn (ms) } & \multirow{2}{*}{$\begin{array}{l}\text { Norm } \\
\text { LatOn }\end{array}$} & \multicolumn{2}{|c|}{ B-PAmp (mv) } & \multirow{2}{*}{$\begin{array}{l}\text { Norm } \\
\text { B-PAmp }\end{array}$} & \multicolumn{2}{|c|}{$\mathrm{CV}$ (ms) } & \multirow[t]{2}{*}{ Norm CV } \\
\hline & & & $\mathbf{L}$ & $\mathbf{R}$ & & $\mathbf{L}$ & $\mathbf{R}$ & & $\mathbf{L}$ & $\mathbf{R}$ & \\
\hline \multirow[t]{4}{*}{ Fibular } & Ankle & EDB & 4.17 & 3.92 & $<4.9 \mathrm{~ms}$ & 2.61 & $* 1.94$ & $>2.13 \mathrm{mV}$ & $n / a$ & $n / a$ & $>42.7 \mathrm{~m} / \mathrm{s}$ \\
\hline & Fib. Head & & 8.83 & 9.50 & & 2.50 & ${ }^{*} 1.24$ & $>2.13 \mathrm{mV}$ & 45.0 & 43.0 & \\
\hline & Pop. Fos. & & 9.58 & 10.75 & & 2.50 & $* 1.22$ & $>2.13 \mathrm{mV}$ & & & \\
\hline & Above Knee & & 11.08 & 11.25 & & 2.53 & ${ }^{*} 1.22$ & $>2.13 \mathrm{mV}$ & & & \\
\hline \multirow[t]{2}{*}{ Tibial } & Ankle & $\mathrm{AH}$ & 4.92 & 4.50 & $<5.6 \mathrm{~ms}$ & 9.35 & ${ }^{\star} 2.45$ & $>6.5 \mathrm{mV}$ & $\mathrm{n} / \mathrm{a}$ & $\mathrm{n} / \mathrm{a}$ & $>40 \mathrm{~m} / \mathrm{s}$ \\
\hline & Pob. Fos. & & 10.42 & 15.92 & & 8.41 & 0.36 & & 63.6 & 27.2 & \\
\hline \multirow{5}{*}{$\begin{array}{l}\text { Sup. } \\
\text { Fibular }\end{array}$} & Lower leg & Ankle & 1.60 & NR & $<5.3 \mathrm{~ms}$ & 10.17 & NR & $>5 \mathrm{uV}$ & 87.5 & NR & $>39 \mathrm{~m} / \mathrm{s}$ \\
\hline & & & 1.63 & NR & $<5.3 \mathrm{~ms}$ & 11.46 & NR & $>5 \mathrm{uV}$ & 85.7 & NR & $>39 \mathrm{~m} / \mathrm{s}$ \\
\hline & & & 1.58 & NR & $<5.3 \mathrm{~ms}$ & 10.81 & NR & $>5 \mathrm{uV}$ & 88.4 & NR & $>39 \mathrm{~m} / \mathrm{s}$ \\
\hline & & & 1.62 & NR & $<5.3 \mathrm{~ms}$ & 10.11 & NR & $>5 \mathrm{uV}$ & 86.6 & NR & $>39 \mathrm{~m} / \mathrm{s}$ \\
\hline & & & 1.62 & NR & $<5.3 \mathrm{~ms}$ & 10.34 & NR & $>5 \mathrm{uV}$ & 86.6 & NR & $>39 \mathrm{~m} / \mathrm{s}$ \\
\hline \multirow[t]{5}{*}{ Sural } & Mid calf & Ankle & 2.02 & NR & $<4 \mathrm{~ms}$ & 7.95 & NR & $>5 \mathrm{uV}$ & 69.4 & NR & $>39 \mathrm{~m} / \mathrm{s}$ \\
\hline & & & 2.03 & NR & $<4 \mathrm{~ms}$ & 7.17 & NR & $>5 \mathrm{uV}$ & 68.9 & NR & $>39 \mathrm{~m} / \mathrm{s}$ \\
\hline & & & 2.00 & NR & $<4 \mathrm{~ms}$ & 7.61 & NR & $>5 \mathrm{uV}$ & 70.0 & $N R$ & $>39 \mathrm{~m} / \mathrm{s}$ \\
\hline & & & 2.00 & NR & $<4 \mathrm{~ms}$ & 9.14 & NR & $>5 \mathrm{uV}$ & 70.0 & NR & $>39 \mathrm{~m} / \mathrm{s}$ \\
\hline & & & 2.03 & NR & $<4 \mathrm{~ms}$ & 7.43 & NR & $>5 \mathrm{uV}$ & 68.9 & NR & $>39 \mathrm{~m} / \mathrm{s}$ \\
\hline
\end{tabular}

Abbreviations: AH-abductor hallucis; B-PAamp-baseline to peak amplitude; CV-conduction velocity; EDB-extensor digitorum brevis; fib-fibular; L-left; LatOn-latency onset; ms-millisecond; mV-millivolts; Pop. Fos.-popliteal fossa; R-right

of one week. Electrodiagnosis confirmed motor and sensory fibular nerve, tibial motor, and sural nerve axonopathies resulting from the entrapment. Constrictive strapping, in this present case, led to under-reported iatrogenic focal nerve injuries. This led to the patient developing dysesthesia (cutaneous symptoms characterized as electric and needle pins sensations) [5], touch allodynia (pain due to a stimulus which does not normally provoke pain) [6], and weakness of her right foot. Biochemical tests are done to determine possible metabolic or autoimmune causes, which in our patient revealed no significant findings. By way of a case report example of limb entrapment neuropathy, posttraumatic saphenous nerve injury occurred due to scar tissue formation. Percutaneous neurolysis and fat grafting appeared to have addressed the clinical issues of the aforementioned case. [7] While it is true that one should address the underlying cause of the compression neuropathy [8], and as was apparent in this present case, it may also take a longer time to manage neuropathic pain. Amitriptyline and gabapentin were taken for 6 months alluding to the importance of longer use of medications to attain efficacy in our present case. Amitriptyline and gabapentin are highly recommended for neuropathic pain based on guidelines. $[9,10]$

\section{CONCLUSION}

This present case highlights the occurrence of focal entrapment neuropathies involving sensory and motor nerves of a limb following constrictive strapping. Our case exemplifies a preventable type of entrapment neuropathy had there been a proper restraining method applied by medical personnel.

\section{Consents and Declaration of competing interest}

An Informed written consent was duly signed by the patient in the presence of senior author, Dr. Raymond Rosales. The Consent included Case presentation, electrodiagnostic tests and Case reporting. No competing interest nor conflict of interest were declared. 


\section{REFERENCES}

1. Hanna AS. Nerve entrapment syndromes treatment \& management: Medical therapy, intraoperative details, complications [Internet]. Medscape; 2021 [cited 2021 Dec 25]. Available from: https://emedicine.medscape.com/ article/249784-treatment\#d9

2. He Y. Allodynia [Internet]. StatPearls [Internet]. U.S. National Library of Medicine; 2021 [cited 2021 Dec 25]. Available from: https://www.ncbi.nlm.nih.gov/books/ NBK537129/

3. Hammi C. Neuropathy [Internet]. StatPearls [Internet]. U.S. National Library of Medicine; 2021 [cited 2021 Dec 25]. Available from: https://www.ncbi.nlm.nih.gov/books/ NBK542220/

4. Schmid AB, Fundaun J, Tampin B. Entrapment neuropathies: A contemporary approach to pathophysiology, clinical assessment, and Management. PAIN Reports. 2020;5(4):e829.

5. Shumway NK, Cole E, Fernandez KH. Neurocutaneous disease. Journal of the American Academy of Dermatology. $2016 ; 74(2): 215-28$.

6. Jensen TS, Finnerup NB. Allodynia and hyperalgesia in neuropathic pain: Clinical manifestations and mechanisms. The Lancet Neurology. 2014;13(9):924-35.

7. Ulloa M, Coronel Banda M. Scar tissue causing saphenous nerve entrapment. Plastic and Reconstructive Surgery - Global Open. 2017;5(9):e 1495.

8. Azhary H, Farooq MU, Bhanushali M, Majid A, Kassab MY. Peripheral neuropathy: differential diagnosis and management. Am Fam Physician. 2010;81 (7):887-92.
9. Moore RA, Derry S, Aldington D, Cole P, Wiffen PJ. Amitriptyline for neuropathic pain in adults. Cochrane Database Syst Rev [Internet]. 2015;(7):CD008242. Available from: http://dx.doi.org/10.1002/14651858.CD008242. pub3

10. Dosenovic S, Jelicic Kadic A, Milianovic M, Biocic M, Boric $K$, Cavar $M$, et al. Interventions for neuropathic pain. Anesthesia \& Analgesia. 2017;125(2):643-52.

(c) (i)(2) Open Access This article is licensed under a cer ${ }_{\text {BY }}$ SA Creative Commons Attribution-NonCommercialShareAlike 4.0 International License, which permits use, share - copy and redistribute the material in any medium or format, adapt - remix, transform, and build upon the material, as long as you give appropriate credit, provide a link to the license, and indicate if changes were made. You may do so in any reasonable manner, but not in any way that suggests the licensor endorses you or your use. You may not use the material for commercial purposes. If you remix, transform, or build upon the material, you must distribute your contributions under the same license as the original. You may not apply legal terms or technological measures that legally restrict others from doing anything the license permits. The images or other third party material in this article are included in the article's Creative Commons license, unless indicated otherwise in a credit line to the material. If material is not included in the article's Creative Commons license and your intended use is not permitted by statutory regulation or exceeds the permitted use, you will need to obtain permission directly from the copyright holder. To view a copy of this license, visit https://creativecommons.org/licenses/by-nc-sa/4.0/. 